\title{
Discussing Legal Protection of the Employment of College Graduates
}

\author{
Xiaozhen zhang \\ Hebei Vocational \& Technical College of Building Materials, Qin huang dao city wenyu road No.8, Hebei Province, China \\ Xiaozhen zhang@021223@163.com
}

\begin{abstract}
In the current severe employment situation, College graduates employment problem has been found. Because of the country's employment law system is not sound, lack of government regulation and graduates themselves legal knowledge, Damaged problems of their own legitimate rights and interests often occur in signing the employment contract and employment process. The significance of discussion on the legal protection of the employment problem of college graduates from higher education, national legislation and administrative functions, safeguarding their legitimate rights and interests, promoting their successful employment is profound.
\end{abstract}

Index Terms - college graduates employment Legal safeguard

\section{Introduction}

Since twenty-first Century, our country's higher education changes from "elite education" to " popular higher education" gradually, With the implementation of " popular higher education", the problem of graduates' employment problem appeared, Among them, the personal rights and interests protection in the process of graduate employment problem is becoming more and more outstanding. Due to the imperfect related legal system, insufficient government regulation, the lack of legal knowledge the students themselves, the college students graduates often face legal disputes and disoriented in the employment process, can not maintain their legal rights and interests, which cause mental and physical or property damage.

\section{The Environment of Legal Problems of University Graduates Employment}

Since the 1990 s, China's economy is the sustained and rapid development. In order to meet the need for senior talent and rapid economic development, the college enrollment is to further expand. 2003 is the first peak of employment years of Chinese universities after enrollment expansion. A total of 2.12 million college graduates, employment difficulties began to appear. The next few years, the number of college graduates increased year by year, By 2013, the number of graduates reached 6.99 million people, 4.87 million more than in 2003. According to the Ministry of education data, the 2014 college graduates will reach 7.27 million. It is known from the above data, the number of college graduates in the job demand continues to increase exponentially, Follow close on succession of college graduates' employment problem, Not only "The work is hard to find" phenomenon appeared ,but also the legal issues for the process has been very prominent.

\section{The Legal Problems of the Employment of University Graduates}

1) The employment contract is not strict, so the graduates labor rights are violated

"Labor contract law" is the basis of sign labor contract, also be the basis of graduates to maintain their own rights and interests. Signing employment agreement with employers, in the trial period or after the entry, Graduates will sign labor contract with the employer. Before signing the labor contract with the employer, Graduates should know that a labor contract should have the following basic content: the name of employer, address and legal representative or the principal person in charge; Labor contract deadline; Working content and working place; Working hours, Rest and vacation; Labor remuneration; Social insurance; Labor protection, Working conditions and occupational hazard protection and other matters shall be incorporated in the labor contract. At present, in addition to legal related professional graduates on the labor contract essential elements are more familiar with, other graduates lack the knowledge. In the face of some samples of the employing units to provide contract, graduates consider only to get a job, Even graduates are not clear or don't understand the essential terms and conditions of the contract, but still sign the inappropriate labor contract. Such as the probation period long, deletion, social insurance, labor remuneration false and abuse by payment, this left hidden trouble for the future of the adults.

2) Employment discrimination phenomenon exists generally, the right to equal employment of graduates cannot be guaranteed.

Equal employment rights can also be called "equal rights of employment", which is a basic rights from the constitution of our country, In paragraph 2 of article 33 of the constitution, citizens of the People's Republic of China are equal before the law. Article 42, the citizens of People's Republic of China have the rights and obligations of labor. in paragraph 1 of article 48,women of the People's Republic of China shall enjoy equal rights with men in political, economic, cultural, social and family life and other aspects. Equal employment rights refers to the equal rights in employment opportunities. The biggest challenge of equal right to employment is widespread discrimination in employment. At present, college graduates often encounter all kinds of discrimination in employment, gender, age, height, household registration, professional, school are likely to become discrimination, and even blood type, the surname may experience discrimination. 
In particular, the sex discrimination has become the primary obstacle of contemporary female college students' employment. The employer recruitment information often can be seen "male priority", or even "men only" words, Although some employers don't stated explicitly, but in the recruitment process they lit the "red light" to female college students'. This violated the female university graduates employment equality in the very great degree.

\section{3) Employment fraud have occurred from time to time}

The scholar thinks, the laborer's right to know is a kind of legal right, refers to the laborer shall have the right to know or understand the relevant information or intelligence to realize their rights of labor. The job market for college graduates is the "two-way choice", but due to the severe employment situation, it becomes a "buyer's market" by the employer. College students know little basic information of employer, and even do not know completely, when they asked the relevant information, the employer always carefully conceal mentioning, In addition, after the interview employers will never tell you the reason lapin. What is more, some employers to one's private ends, use all kinds of tricks in the recruitment of graduates, set traps in employment. In the recruitment, some employers exaggerated unit scale, development prospects, salary, or hiding the truth, malicious deception, declared that "high salary", "high welfare", "high position", They lure graduates to do the work of a misfit and seriously damage the interests of graduates themselves. For example, some companies use low wages and high bonus system to attract applicants, declared that if done well salary will reach million yuan. In fact, the staff can only receive harsh sales commission in almost no basic salary case. All these will lead to the asymmetry of information between graduates and employers and caused the right infringement of graduates.

\section{To Explore the Legal Safeguard Measures of Employment of College Graduates.}

\section{1) Popularization of legal knowledge in the process of employment guidance}

College Students' employment guidance is part of occupation guidance, focusing on the graduates of the occupation guidance and employment services, mainly to help students to master the laws and regulations related to employment; to guide students to establish the correct idea of choosing a job, a correct understanding of self, to know occupation, to set up the good occupation moral; to train ability for graduates to choose occupation; according to the employment volunteer of graduates and occupation ability, psychological quality and other factors recommended the employment guidance for graduates to find employment information and the correct selection. In the occupation guidance process, laws and regulations related to employment education is particularly important for graduates, it can avoid the legal problems of employment in certain extent, and can help the students to solve the legal problems in employment. In practice, More universities achieve in the form of lecture with a limited audience, Due to various reasons, some students didn't attend lecture and did not reach the expected effect. According to the actual situation of employment of college graduates, Graduate Employment Guidance of laws and regulations should be a required course arrangement in graduation year to popularize the relevant laws and regulations for graduates.

\section{2) Constructing the legal relief system of equal employment rights of College students}

The elimination of discrimination in employment of college graduates, the whole society should take the cultivation of consciousness of anti discrimination in employment, the government set up monitoring mechanism of employment market and employment market self-discipline management, but more effective way is to state regulation in the legislation and to establish the system of college graduates employment rights of legal relief right, so that they get the final guarantee. The State shall formulate the "anti employment discrimination law", which make clear the meaning and definition of employment discrimination, through the methods of supporting each other with list and general terms, all the employment discrimination were incorporated into the adjustment of the law, and the employers' autonomy are defined with "post qualification standards" principle. It executes the burden of proof shift rules of evidence, make that clear to the legal responsibility. In the legal relief of the right of labor, employment discrimination disputes will be included in the scope of labor disputes to safeguard the right to fair employment of College graduates. At the same time, Employment Discrimination Litigation system will be established to allow students to the courts to employment discrimination, to break through the traditional "direct interest" principle and to expand the scope of plaintiff, It can play the function of labor union, youth, women's organizations, safeguard public interest litigation according to procedure and safeguard the equal employment rights of graduates effectively.

\section{3) Establishing the right guarantee system of college graduates}

To ensure the implementation of the employment of university graduates' right to know, the government should play a role of administrative functions, supervise and urge the employing units to set up the relevant system. One is an enterprise information disclosure system, the enterprise should provide candidates publicly except the enterprise commercial secret, the enterprise basic information, welfare, labor and social security system; The enterprise should disclose the rules and regulations of labor, labor safety conditions, basic financial information to internal staff. The two is to inform the system of important matters, such as the content which shall be informed by employing units in the "occupation disease prevention law", in addition to corporate welfare, labor protection, production facilities, equipment and the operation conditions in candidates should inform the applicants. Not only enterprises should set up related system, but also shall supervise the implementation system and stipulate the responsibility in administrative legislation mode. 


\section{References}

[1] Junxiu Xu. Analysis of legal protection of employment of college students. occupation time, 2007 (20)

[2] Lihua Luo, Bin Yan. Equal employment right on. Journal of Changsha University of Science and Technology, 2007,22 (3)
[3] Hongmei Chen college graduates employment discrimination law relief, Journal of China Youth University for Political Science, 2011 (6)

[4] Huyong Zhou. Construction of the relief system, Employment Discrimination Litigation China labor, 2008 (3) 